\title{
Citizens Educating Themselves: The Case of Argentina in the Post-economic Collapse Era
}

\author{
Luis-Alberto D'Elia \\ University of Alberta \\ E-mail: 1delia@,ualberta.ca
}

A review of the literature reaffirmed that research and visions related to Adult Basic Learning and Education in the South are dominated by the North, by international agencies and by English-speaking reviewers, who often ignore or dismiss research produced in the South especially if it is written in languages other than English (Torres, 2004).

\begin{abstract}
In reviewing some of the particular contexts in which hundreds of thousands of Argentineans have been organizing and educating themselves around and after the time of the country's recent historical crisis, I will be looking at relevant work done by researchers and educators paying special attention at those coming from South America, and, in particular, from Argentina. The intention of this article is to look critically into the exceptional socio-cultural-political conditions that enable Argentinean "crisis" new movement groups to seek out and practice uncompromising, autonomous ways of adult and collective non-formal and informal education.
\end{abstract}

\section{Introduction}

Argentina, a country that after World War II was considered the "grain supplier of the world," and the nation that at one time had one of the most stable social systems (under the Peronist era), collapsed socio-politically and economically in a very dramatic fashion following 2000. At the same time that crisis almost completely wiped out the country's majority middle class socially, it also set a historical precedent when Argentina defaulted in the payment of its foreign debt owed to the International Monetary Fund (IMF) and related organizations. In fact, in December 2001 the government defaulted on approximately $\$ 140$ billion in debt, the largest sovereign debt default in history (Feldstein, 2002). Shortly thereafter, Argentina's currency (the Peso) and banking system collapsed: the country sank further into a depression. Prior to the collapse, a shaky Argentinean government sequestered the savings of the once dominant and strong middle class, immediately sending this large group of people to join the already growing poor and destitute underclass. Clearly, the country was in a complex and multifaceted crisis (Weisbrot, 2005; Armelino, M.; Bruno, M.; Larrondo, M.; Patrici, N.; Pereyra, S.; Perez, G. et al, 2002; Klein, 2003; Palomino, 2004; Lodola, 2003; Monteagudo, 2004). An almost immediate collective response to the crisis arose, followed by the quick formation of an unprecedented social movement that not only managed to depose five country Presidents in a single week, but that also led to the creation of a new form of socio-economic-organizational survival that surprised Argentinean crisis analysts around the world (Lodola, 2003; Klein, 2003). This paper discusses characteristics of this movement and should provide insight into the unique historical formation of a citizens' informal and autonomous education movement.

Journal of Contemporary Issues in Education, 2006, 1(2), pp. 38-48.

ISSN 1718-4770 @ 2006 University of Alberta

http://ojs.educ.ualberta.ca/index.php/jcie/ 


\section{The Social Groupings of the Crisis}

As Klein (2003, p. 1 ) has noted,

With all of their institutions in crisis, hundreds of thousands of Argentinians [sic] went back to democracy's first principles: neighbours met on street corners and formed hundreds of popular assemblies. They created trading clubs, health clinics and community kitchens. Close to 200 abandoned factories were taken over by their workers and run as democratic cooperatives. Everywhere you looked, people were voting..

The crisis generated a popular movement whose most important characteristic was a purposeful effort to be autonomous and independent of any organized socio-political structure. Whether they were piqueteros (groups of unemployed, economically-disenfranchised middle class), food rioting groups, or neighbourhood assemblies, these Argentinean associations were radically opposed to past and current socio-political experiments (Armelino et al, 2002; Klein, 2003; Lodola, 2003). Most importantly, they were securing an unprecedented change in the way social movements would relate to social agencies, in general, and to established world powers, in particular. The movement resisted, with huge, visible and tangible success, government attempts to assimilate them into its structures and, who were not willing to join any specific political parties, or other established social and labour movements, including Non-Governmental Organizations (NGOs). The new social arrangements clearly had a communal consciousness in fighting a corrupt government and planning for life in self-sustainable and self-sufficient ways. They were prepared to dispense with the country's political leaders who seemed incapable of responding in any way and who, in the people's minds, were therefore invisible. For example, at frequent massive demonstrations during the height of the crisis, hundreds of thousands of Argentinean would chant "ique se vayan todos, que no quede ninguno!", "all of them [all state representatives, politicians] leave! No one should stay over!" (Armelino, 2002; Auyero, Patrick \& Moran, 2001; Palomino, 2004). This extraordinary rebellion against assimilation and dependency on old structures appears to signal a parallel autonomy by new movement members towards teaching and learning for themselves and by themselves.

\section{Autonomous Groups, Creative Pedagogy}

In looking back at these situations and in observing current social structures in Argentina, one may see that there are hundreds of autonomous organizations in Argentina. Their autonomy from institutional and political powers is unique and was virtually non existent in socio-political groups of Argentina during the 1980s and the 1990s. Monteagudo (2004) predicts that these groups will likely remain this time, transcending the temporality that characterized similar groups during previous crises. Although there were no organized or street-based educational projects that may have 'conscientized' the rebelling public this time, clearly there were spontaneous and informally located learning interactions that people have shared and operationalized to achieve a viable social change vis-à-vis the powers that be. However, this type of informal education may not last if it is not sustained via an organized social program that also gives important and long-term meaning to both the formation of new social movements and

\footnotetext{
${ }^{1}$ Translation of original phrases in Spanish translated by the author.
} 
the historical affirmation of these movements. As Monteagudo (2004) notes, the task still needs more work, for thus far, "they have not been able to stabilize that energy in structures that will enable them to grow and succeed. Perhaps, if these autonomous groups continue to prosper in the future and are able to unite in decentralized structures, that will change" (p. 1). With autonomous and sustainable social groupings, we can hope for a pedagogy that is characterized by its independence from institutional, political and structural powers and interests. As noted above, some of that pedagogy has at least started to become more evident in the recent years.

\section{Sterilization of Reproductive Education - Discontinuation of Capitalism Profiting From Education}

According to Weber, power is the realization of the human will even against the resistance of others (Weber as cited in Murphy, 1988). And we could say more about the sociological concept of power by referring to Baldus (1975) definition, where power can be seen as the ability of a "center unit," in a structure of social inequality, "to maintain, reproduce, or reinforce" its position with respect to a "periphery unit" (p. 188). Furthermore, Murphy (1988) defines a very subtle power subcategory: the power of a unit "to profit from," which is defined as the "capacity to take advantage of possibilities that are presented by others". In the particular case of societyschool relationships, Murphy explains that the bourgeois class has "the power to profit from educational knowledge and to constrain...the definition of what counts as educational knowledge" (p. 148) (author italics). To what degree is this type of almost imperceptible power influencing the educational process in the new Argentinean movements?

Furthermore, considering that most sociological theories of education assume that the school and educational systems are highly dependent on wider society, (that is, society's dominant groups), and the latter has demonstrated power over the schooling (Parsons; Bowles \& Gintis; and Young; as cited in Murphy, 1988), it is important to examine how the Argentinean autonomous movement enters into the education-society power equation. When attempting to draw any conclusions from these power relationships, one has to consider that Argentinean society has not been an exception to the hegemonic capitalist and neo-liberal model, and that it is still debatable whether the dominant groups in society have the power to profit from education because the educational (schooling) systems have adapted to the capitalist system (Murphy, 1988). Regardless of the validity of the latter point, in the current autonomous movements of Argentina, the opportunities for dominant groups in Argentinean society to have the power to profit from the education of their members will be directly proportional to the degree of assimilation of the new groups to the institutional, labour and political structures of the country.

Another opportunity for the Argentinean capitalists to profit from their groups' efforts to educate and train their members is by incorporating those members into their production machinery (employing them under the regular market rules). However, in the autonomous groups that emerged around and after the crisis in Argentina, there are a variety of situations that exempt them from having to negotiate their education and organizing efforts within the established capitalist system. These situations would include the fact that a good number of the assembly members (asambleistas) are not entering the capitalist labour force but, rather, are creating their own micro-enterprises (home businesses) (Klein, 2003, Lewis, 2004). In addition, some of the groups of piqueteros have decided to continue working on the state-plan program, escaping, in this way, the dependency on the private capitalist employers (Lodola, 2003). Finally, the unemployed masses who took control over the abandoned factories are now running them as 
cooperatives and rejecting the organization of their business within a profit distribution system similar to the capitalistic approach (Klein, 2003).

Consequently, it appears the characteristic of autonomy amongst the piqueteros, asambleistas, and hundreds of thousands of Argentinean organized around and after the crisis, protects them from being vulnerable in the society-education power relationship. Specifically, Argentinean workers that escaped regulation by capitalist economic interests are "agua para su propio molino" (bringing water to their own well) and serving their own educational needs.

\section{Liberating From State-Dependency}

Klein (2003) argues that the popular neighbourhood assemblies that brought together large groups of labourers, unemployed workers and middle class, kept their commitment to remain autonomous from any previously organized, and, often, corrupt, structures. Participants to the assemblies carefully negotiated all socio-political terms with a lot of care so as to protect their independence in relation to other influences from outside. Klein was a witness to the outstanding autonomy of the groups. It is clear any invitation by politicians to discuss social issues would be rejected, with the exception of when a politician would come to where the assemblies were congregated, that is on the streets, or in other public places at the neighbourhood corner. The assembly members did not allow for any indirect representation of their popular demands because they suspected that middle persons, might, one way or another, be attached to politicians, brokers or gatekeepers, even fearing that one of their own could water down their demands, or betray them, a reality known only too well that happened on many occasions before the crisis. Undoubtedly, the potential for these autonomous groupings to create new educational ways, independent of institutionalized pressures, is exceptional.

\section{Independence in a Traditional State-Patronizing Nation}

One can argue that the social groups' dependency on the state has been characteristic of Argentinean society since the Peronist regime, and that dependency will likely characterize these new organizations, in spite of the crisis. Although it is correct that a fundamental socio-political arrangement was present in Argentina as inherited from the Peronist regime in the form of the cliental system led by "punteros" (social brokers), at the time of the crisis the state failed to sustain the system (Auyero, Patrick \& Moran, 2001). The punteros, who would traditionally mobilize the poor and working class neighbourhoods for elections and other political activities, and who would be in charge of the distribution of state welfare benefits and, likely, educational strategies at the neighbourhood/community level, continued to play their roles during the crisis. However, during the crisis the political/institutional relationship changed. One illustration comes from the punteros' activities during the 2001 food riots. During the violent weeks of the riots, brokers [punteros] looked for food outside of the usual places and did not use the usual means. In fact, traditional state programs that had been the sources of food for the punteros' clients "were not responding," and the brokers turned their attention to local supermarkets.

Certainly, as the crisis continued to intensify in Argentina, a majority of the people were left with nothing to lose and possibly something to gain. They started to restore their sense of autonomy and to remove the support base away from the deceitful structural powers and transfer that support base to their own communities. It was in this way that many Argentineans began to create new ways of organizing, teaching and learning. 


\section{Outside Academia}

Most piqueteros, asambleistas, factory-take-over workers, and other Argentinean, who congregated into hundreds of new socio-political groupings, undertook their teaching/learning with a similar philosophical approach as that used in their organizing: autonomous, self-reliant, independent of external interests and powers, and strictly locally-regionally-driven and mobilized.

If the educational experiences of these Argentinean crisis groups are characterized by autonomy and independence from established institutional and political interests and powers, it is evident that these groups will not use formal systems of education but, rather, will use informal and non-formal ones. At the same time, it is understandable that in times of deep institutional crisis, and when basic socio-economical-political tenets are being questioned as they have been in the case of Argentina, the most non-conventional, extra-institutional forms of education will be adopted by members of the groups. Consequently, we may expect to find that an informal educational category will be the most popular amongst group members. In defining informal learning, Livingstone (cited in Schugurensky, 2000, p. 1) says that informal learning can be seen as "any activity involving the pursuit of understanding, knowledge or skill which occurs outside the curricula of educational institutions, or the courses or workshops offered by educational social [or corporate] agencies" (p. 1).

\section{Informal Education}

Amongst others, piqueteros and the assembly movements have been exploring strategies of informal education. However, an important characteristic of their educational approach has been their uncompromising autonomy from established forms of organized education. One important reason for the new movement to take such an anarchist positioning has been explained previously: the absolute deception by organized governmental or non-governmental structures during the crisis in Argentina.

How has the informal education been implemented by the participants of these movements? Besides the highly valuable informal learning that happens in the lives of citizens as they organize themselves to attend to their basic survival needs members of piqueteros, or assembly organizations, organized their education with more intentionality and started asking the popular educators to organize immediate and needed areas of learning. One of such educators group organized the Área de Educación Popular del Movimiento Barrios de Pie (Movement Barrios de Pie's - Neighbourhood Standing Up's - Popular Education in 2002) (Barrios de Pie, 2002). This strategy focussed on collective projects such as "popular education with children, literacy and post-literacy; elementary and high school completion"; workshops (in Argentinean and Latin-American); history and political education for leaders and participants of neighbourhood soup-kitchens; a diversity of other workshops, such as trade work and popular assemblies' participatory techniques, and travelling workshops; and, discussed topics such as the proposed "Free Trade of the Americas" (FTA)(ALCA in Spanish), and, foreign debt, among others (Movimiento Barrios de Pie, 2005). In fact, socio-political themes that are part of the context of their existence and survival could not be absent; moreover, as evidenced later, these are generic parts of the people's daily existences. 


\section{Non-Formal Education and Literacy Programs}

Literacy programs in Latin America throughout the 1970s have been characterized by their critical approach: raising the consciousness of illiterate adults and educating the participants in questioning predominant social and political oppressive structures (e.g., Ligas Agrarias which educated farmers in understanding, among other things, the underlying factors of their poverty and dependency). Programs like these are usually part of non-formal education due to their structure, planning and participation of formal social and development agencies in their implementation. However, there is a need to examine their influence in the particular circumstances of the Argentinean crisis over literacy programs in order to identify possible differences between the crisis' literacy programs and those of traditional programs.

Some of the literacy programs implemented in Argentina in the recent years have adopted a Freirean philosophical approach as evidenced in the use of a "popular education" pedagogy. In a popular education process, learners learn about their own socio-political oppressed situation using their own expressions and are encouraged collectively to become active participants in the process of their own liberation (Freire, 1970). Freire's popular education is critical education with its assumption of the crucial role that education plays in uncovering and changing society's unjust structures of oppression ${ }^{2}$.

In a recent national meeting of popular educators in Argentina, it became clear that the popular education programs targeting illiterate adults and other learning groups covered a number of group-relevant issues and strategies. At the same time, the general conceptualization of popular education as not only "popular" in terms of free access, with a bottom-up approach that is community-oriented and non-governmental in nature, but also and in terms of its informality, as Coco, a popular educator from Buenos Aires, put it:

The popular educator is not a person that learns about how to educate from books. Popular education is not a thing that it can be found [only] in books, it is a concept. Popular education is a political act: it is present every day wherever there are compañeros [comrades] in the struggle. Popular education is there. There are also the popular educators. They are in the piquete [picketing], in the marches, in the student's center. Popular education is in every corner where we meet and where we take decisions (Barrios de Pie, 2002).

A more traditional (massive) literacy program has recently been borrowed from Cuba by two Argentinean popular education organizations, the "Yo, sí puedo" ("I am surely capable") program. The program caught the attention of the organizers after visiting the program overseas and, later, realizing the huge task involved to implement popular education in Argentina. The program is a literacy-based, audiovisual program for adults provided to the Argentinean Barrios de Pie by IPLAC (Instituto de Pedagogos de Latinoamérica y el Caribe) and by the UMMEP ('Un Mundo Mejor es Posible') (Movimiento Barrios de Pie, 2002, 2005). Will this structured pre-packageded program and structurally organized educational strategy work for the vast majority of those who lost trust in any structured or institutionalized help?

\footnotetext{
${ }^{2}$ My personal experiences with Freirean pedagogy in 1970 at the Federal University of Santa Maria, Rio Grande do Sul, Brazil, confirm this.
} 


\section{Education and New Trade Unions}

In speaking about this issue, Livingstone \& Sawchuck (2005) wrote that

...working-class peoples' indigenous learning capacities have been denied, suppressed, degraded or diverted within most capitalist schooling, adult education institutions and employer-sponsored training programmes, at the same time as working class [sic] informal learning and tacit knowledge are heavily relied on to actually run paid workplaces (p. INSERT PAGE NO).

Even though this research takes place in North America, a possible generalization about the researchers' work can be applied to the Argentinean workers since the Argentinean government (most importantly under the Menem administration in the late 1990s) structured the functionalities of the country in line with a so called "knowledge-based economy". In a knowledge-based economy, expert knowledge is validated over workers' Indigenous learning. Under this assumption, most workers would be considered to have educational deficits which, according to Livingstone and Sawchuck (2005), reflect the human capital concept of education relevant to a knowledge-based economy, even if trade unions, nevertheless, have been the "primary sites of working class [genuine] learning" (p. 110-111).

The Argentinean trade unions have historically organized around a central national confederation, the General Confederation of the Workers (CGT, Central de Trabajadores Argentinos). This traditional (Peronist) organization has been criticized as corrupt in siding with the country's economic and political powers. Other confederations and labour union groupings have emerged in the recent history of the country. One of them, popular around the time of the recent Argentinean crisis, is the Central de los Trabajadores Argentinos (CTA), an alternative national union confederation to the CGT. The CTA defines itself as a "new confederation of workers, employed or unemployed, founded on three essential concepts: direct affiliation, outmost democracy, and political autonomy" (CTA, 2000).

We can expect that informal and non-formal learning happen both through and as a result of the trade unions. However, around the time of the crisis, the level of confidence in organized labour for many impoverished Argentinean unionized workers, must have decreased significantly. Indeed, even today, structured and institutionalized assistance is going to be rejected by Argentineans since having experienced a long history of deception by government and its institutions. However, if help is perceived as an extension of their labour struggles through their non-corrupted unions, the Argentinean workers, in turn, may trust this helping hand, as may be the case of the CTA. Its educational programs are organized under the Institute de Estudios y Formación (Institute for Studies and Training). As things are now, this could constitute one of the institutional non-formal projects of education that are acceptable to some Argentineans in the crisis movement.

Another popular and quasi-institutionalized non-formal form of education is one offered through the predominantly Roman Catholic Church's social agencies such as Cáritas (Cáritas, 2005). Throughout its different programs and outlets across the country such as "the community services centers, the lunch programs/kitchen soups, the parishes and chapels" there are non formal education initiatives and activities servicing communities, families, and individuals of all ages from diverse socio-economic backgrounds (Cáritas, 2005). The pedagogical objective is to encourage people's capacity to be "critical and autonomous" (author italics). In the case of 
children, Cáritas programs tend to socialize children into mainstream schooling in Argentina. Nevertheless, in the latter case, the church's agency understands the need to go beyond the formal education offered by the schools. In spite of the highly structured institution to which it belongs, some of the Caritas chapters (in some provinces) have been able to selectively respond (quite faithfully) to the needs of the poor and the negatively affected middle class. As such, they have developed, of note, a good reputation, not only among the communities they serve but also among the general population, especially in some regions of the country. Criticized as being "asistencialista" (providing only band-aid assistance and not dealing with the structural roots of the social problems) by other social agencies who may have been suspicious of any pronounced disengagement by Cáritas from the powers that be during the crisis, to its credit, Cáritas was one of the few mainstream institutions trusted by disillusioned Argentineans in some areas of the country. This may be due, in part, to the high level of community-based development and participation that Caritas has in its programs ${ }^{3}$. Indeed, based upon the experience in living through both locally and globally induced oppression, complemented by the informal training workers and progressive trade unions have achieved to fight against the central government and its formalized institutions, citizens' movements should be able to see and recognize the good work of groups such as Cáritas are undertaking as having a genuine interest in the lives of Argentina's disenfranchised.

\section{Conclusion}

In this essay, my intention is to attempt to present a unique educational analyses that pertains to the situation in Argentina since the economic crisis of 2002. By and large, the analyses have been intended to prospectively discuss analyze the very active intersections that characterized the needs of the public and the activities/programs they were trying to achieve so as to overcome the difficult situation in which they found themselves after the sudden loss of their purchasing capacity, indeed, their economic viability after this globally induced crisis. It is on this spirit and inclusive understanding that this article attempts to take a critical look into the exceptional sociocultural-political conditions that enable Argentinean new movement groups that emerged during and after the recent crisis in attempts to search for and practice uncompromising, autonomous ways of non-formal and informal education. The reality is that in the lives of the common man and woman, the recent Argentinean crisis had apocalyptical proportions and generated a collective response that unleashed an unprecedented social movement to resist assimilation by the government, political parties, established social and labour movements, and even NGOs. This resistance and autonomy is accompanied by a parallel autonomy by new movement members to teach and educate themselves. Through that new found autonomy, the new movement not only broke off with the deceptive powers of the past, creating new organizational and educational spaces, it also managed to escape the Argentinean capitalist's power to profit from the education of the new movement's members. But what forms have this educational process taken? It was, the case, for example, that piqueteros, the assembly and other crisis movements, amongst others, have also been exploring strategies of informal education.

\footnotetext{
${ }^{3}$ My personal experience in working with Cáritas in Entre Ríos Province for many years. Since 2000, I have met with some community programs participants, natural leaders, and Cáritas management. I have travelled to visit specific community projects with an educational component in Paraná city and in small towns and villages of Entre Ríos Province.
} 
However, this informal education takes a particular shape in these popular movements. Through their "popular educators," piqueteros, or assembly organizations, have been focussing not only on children's popular education, literacy and post-literacy, but also on historical and political education for leaders and participants of neighbourhood soup-kitchens, trade workers, and in the participatory techniques of popular assemblies'. Lately, these educators have organized discussions on the proposed "Free Trade of the Americas," foreign debt, and other topics (Movimiento Barrios de Pie, 2005). In fact, socio-political themes are an integral part of these historic social movement shifts and should affirm their survival and long-term existence. Moreover, it appears that the critical examination of the socio-political context in which these movements are immersed is a pre-requisite for other groups' educational undertaking. The nonformal educational strategies, on the other hand, have been used for literacy programs that traditionally in Argentina (as well as in other Latin American countries) have used the popular education of Freirean educational platform. After the crisis, a particular literacy program has been implemented by Barrios de Pie, a crisis group, in collaboration with other Cuban \& Caribbean educational organizations. Other non formal education strategies have come from an alternative trade union confederation. Even though Argentineans organized in post-crisis movements reject structured and institutionalized assistance, if the help is perceived as part of their labour struggles through their non-corrupted unions, the assistance, in this case, training and education, may be acceptable. The national workers confederation, CTA, is providing nonformal education that, far from creating the usual labour dependency, is encouraging its members to gain consciousness about their labour situation.

\section{Looking Forward}

In sum, it is now clear that there are hundreds of organizations in Argentina that are basically autonomous from institutional and political powers (Lodola, 2003; Monteagudo, 2004) and whose informal and non-formal education programs go beyond learning how to organize and survive in the market economy. Indeed, their members are using popular education to understand their own socio-political context to counter-weigh and resist assimilation by an established political system that failed them in the process leading to the crisis. Their long-term survival may be more likely than in previous crises and this sustainability will probably ensure a more effective and systematic informal educational process. This educational process will, in turn, become more important as other counter-current (anti-globalization) movements around the globe look to the Argentinean autonomous groups to learn more of how they can create and manage progressive educational possibilities without compromising their autonomy that, in the Argentinean case, guarantees independence from corrupt and centralized socio-political arrangements. In a recent visit by Michael Hardt to Argentina, he restated that we are living in the final times of imperialism (although a qualified one) and what makes imperial hegemony vulnerable, is not anti-imperialism, but self-management by autonomous groups like the ones in Argentina, Mexico (Chiapas), Brazil (landless movement), and others ${ }^{4}$.

\footnotetext{
${ }^{4}$ Michael Hardt is a well known author who, together with Antonio Negri, theorizes on the "Empire."
} 


\section{References}

Armelino, M.; Bruno, M.; Larrondo, M.; Patrici, N.; Pereyra, S.; Perez, G. et al. ( 2002). La trama de la crisis: Modos y formas de protesta social a partir de los acontecimientos de diciembre de 2001. Facultad de Ciencias Sociales, Universidad de Buenos Aires (Informes de Coyuntura, $\mathrm{N}^{\mathrm{o}} 3$ ). Buenos Aires: Facultad de Ciencias Sociales. Retrieved Oct 15, 2005, from http://www.iigg.fsoc.uba.ar/docs/ic/ic3.pdf

Auyero, J. (2001). La política de los pobres. Las prácticas clientelistas del Peronismo. Buenos Aires: Manantial.

Auyero, J., Patrick, T. , \& Moran (2001 ). The Dynamics of Collective Violence: Dissecting Food Riots in Contemporary Argentina. State University of New York: Stony Brook.

Barrios de Pie, (2002). ¿Qué es el Área de Educación Popular? Retrieved November 10, 2005, from http://www.barriosdepie.org.ar/

Cáritas Argentina (2005). Educacion. Retrieved November 15, 2005 from http://www.caritas.org.ar/htm/educacion01.htm.

Central de Trabajadores Argentinos (CTA), (2002). Retrieved December 2, 2005. http://www.cta.org.ar/institucional/institucional.shtml.

Feldstein, M. (2002). Argentina Doesn't Need the IMF. The Wall Street Journal. Tuesday, May 28, 2002.

Freire, P. (1970). Pedagogía del Oprimido. Mexico: Siglo Veintiuno.

Klein, N. (2003). From pots to politics. The Guardian, Monday May 12, 2003. Retrieved from http://www.guardian.co.uk/Columnists/Column/0,5673,953825,00.html

La Vaca (2005). La autonomía es una arma más fuerte que el antiimperialismo. Interview December 12. 2005. Retrieved on Dec 13, 2005, from http://www.lavaca.org/seccion/actualidad/1/1258.shtml

Lewis, A. (Director). (2004) The Take [film]. Barna-Alper Inc.

National Film Board of Canada (2004). Retrieved November 18, 2005, from http://www.nfb.ca/pop.php?paramLang=en

Livingstone, D., \& Sawchuck, P. (2005). Hidden knowledge: Working class capacity in the "knowledge-based economy". Studies in the Education of Adults, 37, 2.

Lodola, G. (2003). Protesta popular y redes clientelares en Argentina: El reparto federal del Plan Trabajar (1996-2001). Departamento de Ciencia Política, University of Pittsburgh. Pittsburgh:USA.

Monteagudo, G. (2004). July 25, 2004. The Argentinean Social Movements and Kirchner. Blue III, 13. Feature Archive BlueGreenEarth. July 25 2004. Retrieved Nov 27, 2005 from http://www.bluegreenearth.us/archive/article/2004/monteagudo-1-2004.html

Movimiento Barrios de Pie, (2005). Encuentro Nacional de Educadores Populares. Retrieved November 10, 2005, from http://barriosdepie.bitacoras.com/archivos/2005/05/25/primerencuentro-nacional-de-educadores-populares-del-movimiento-barrios-de-pie.

Murphy, R. (1988). Social Closure. Oxford: University Press.

Palomino H. (2004). Un análisis de la 'economía moral' del movimiento autogestionario (Revista Herramienta La Fogata). Retrieved Nov 15, 2005, from http://www.neticoop.org.uy/documentos/dc0396.html 
Schugurensky, D. (2000). The forms of informal learning: Towards a conceptualization of the field. NALL (New Approaches to Lifelong Learning) Working Paper \#19, October, 2000. Retrieved December 2, 2005, from http://fcis.oise.utoronto.ca/ daniel_schugurensky/

Scott, S.; Spencer, B.; Thomas, A. (1998). Learning for life: Canadian Readings in Adult Education. Toronto: Thompson Educational..

Torres, R-M., (2004). Lifelong learning: A new momentum and a new opportunity for adult basic learning and education (ABLE) in the South. Convergence. 37, 3.

Weisbrot, M. (2005). Good news at last! The IMF has lost its influence. Counterpunch. October 12, 2005. Retrieved Oct 27, 2005, from http://www.counterpunch.org/weisbrot10122005.html 